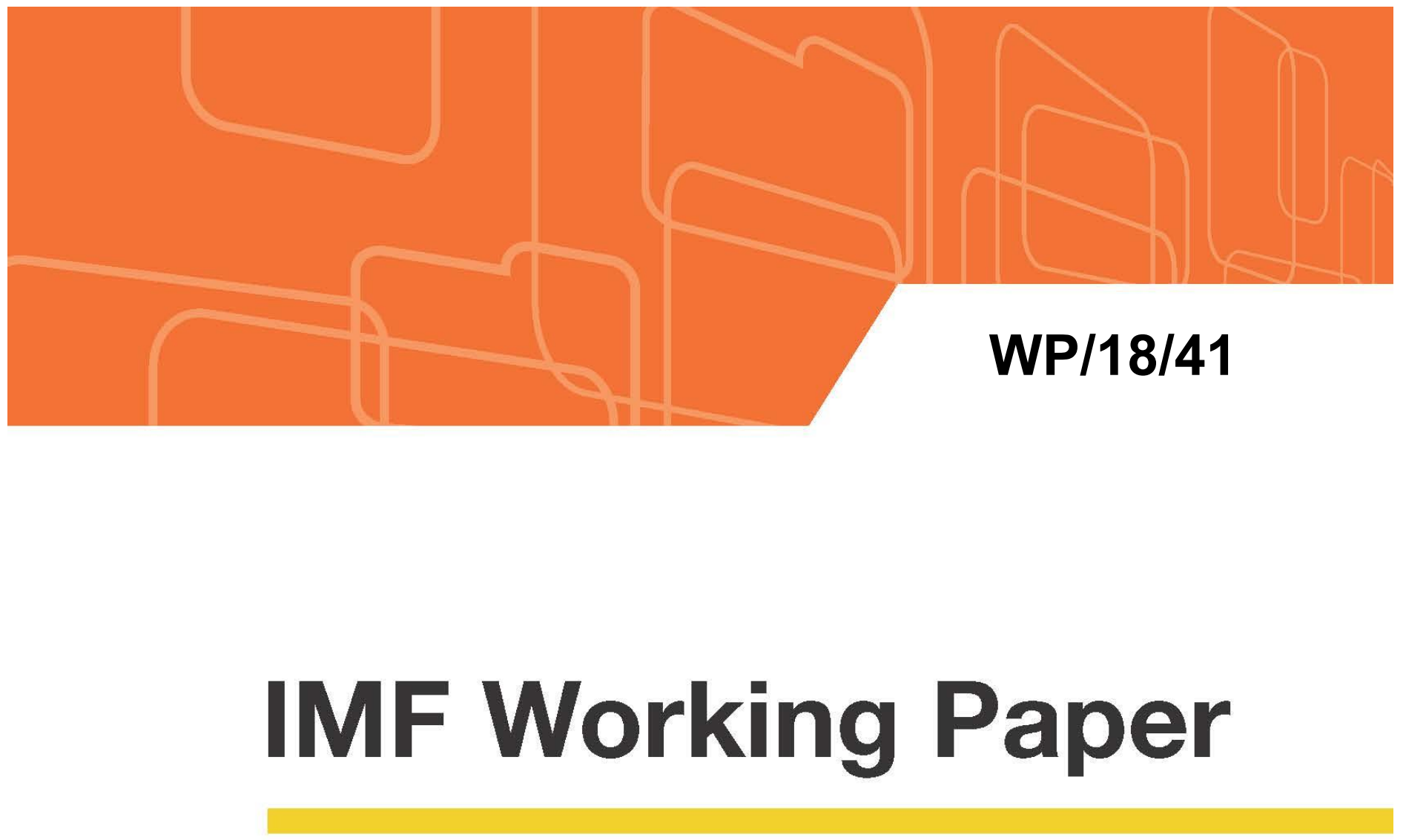

\title{
Sustainable Development Goals (SDGs) and GDP: What National Accounts Bring to the Table
}

by Thomas Alexander, Claudia Dziobek, and Tadeusz Galeza

IMF Working Papers describe research in progress by the author(s) and are published to elicit comments and to encourage debate. The views expressed in IMF Working Papers are those of the author(s) and do not necessarily represent the views of the IMF, its Executive Board, or IMF management. 


\title{
IMF Working Paper
}

Statistics Department

\section{Sustainable Development Goals (SDGs) and GDP: What National Accounts Bring to the Table}

\section{Prepared by Thomas Alexander, Claudia Dziobek, and Tadeusz Galeza ${ }^{1}$}

March 2018

\section{IMF Working Papers describe research in progress by the author(s) and are} published to elicit comments and to encourage debate. The views expressed in IMF Working Papers are those of the author(s) and do not necessarily represent the views of the IMF, its Executive Board, or IMF management.

\begin{abstract}
The Sustainable Development Goals (SDGs) adopted by the UN General Assembly in 2015 represent a new global consensus to end poverty, promote prosperity, and protect the environment. Goal 8 seeks to improve global resource efficiency in consumption and production and to decouple economic growth (GDP) from environmental degradation while Goal 12 focuses on sustainable consumption and production. While GDP does not capture these broader goals, we suggest that the System of National Accounts which incorporates but goes well beyond GDP, can be used for the measurement of these SDGs and to support policy. We construct a conceptual "super balance sheet" with an expanded asset boundary to include durable consumer goods used to produce services, human capital, and access to resources such as clean water and air, education, health, and infrastructure, to produce an expanded household net worth.
\end{abstract}

JEL Classification Numbers: B41, C82, D13, D3, E01, H4, I3, Q2

Keywords: SDGs, Beyond GDP, National Accounts, Balance Sheets Authors’ E-Mail Address: talexander@imf.org; cdziobek@imf.org; tgaleza@imf.org

\footnotetext{
${ }^{1}$ We would like to thank for their useful comments: Louis Marc Ducharme, Johannes Mueller, Gabriel Quiros, Roberto Rosales, Robert Dippelsman, Artak Harutyunyan, Diane Kostroch Marco Marini, and the participants at an IMF Statistics Department seminar. All remaining errors are our own.
} 


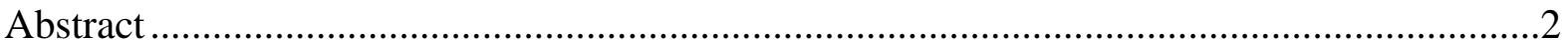

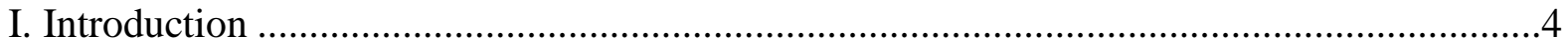

II. SDGs - WHAT THE SNA BRINGS TO THE TABLE....................................................

A. The SDGs and Multidimensional Measures of Progress ...........................................5

B. GDP and the SNA - A Brief Recount of the Evolution...........................................

C. The Relevance of National Accounts to the SDGs ...................................................

III. The SNA Household Sector and Extended Asset Boundary ………………......................10

A. The SNA Balance Sheet for the Household Sector..................................................11

B. The Expanded SNA Assets Boundary ……………………………………...........12

IV. Building an Extended "Super Balance Sheet" ...............................................................14

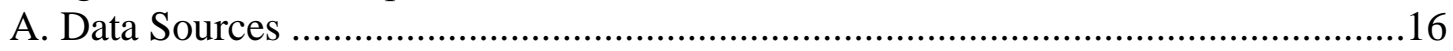

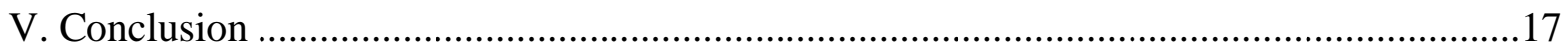

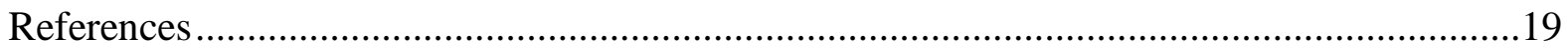

Tables

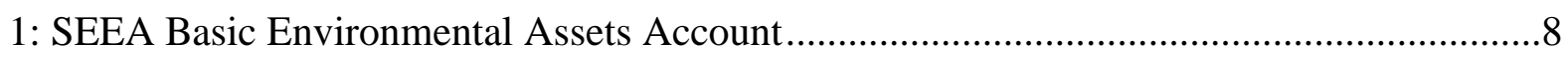

2. Household Expenditure by Region ................................................................................ 11

3. The SNA's Household Balance Sheet (SNA Asset Boundary) .............................................14

4. Beyond GDP: A "Super" Balance Sheet of Households (Extended Asset Boundary ..........15

Figures

1: United Nations Sustainable Development Goals (SDGs) ……...........................................6

2. The SNA Splits the Economy into Institutional Sectors.......................................................

3. SNA - Measures of Wealth of Countries and Changes Over Time …………….................10

4. United States: SNA-Based Household Sector Balance Sheet...............................................12 


\section{INTRODUCTION}

The Sustainable Development Goals (SDGs) adopted by the UN General Assembly in 2015 represent a new global consensus to end poverty, protect the planet, and to ensure prosperity for all. The SDGs address the need for GDP growth to be decoupled from environmental degradation and linked with sustainable production, consumption, and meaningful jobs. We suggest that the national accounts framework, of which GDP is an integral part, can be used to provide a measurement framework to assess sustainable production, consumption, and meaningful jobs.

The System of National Accounts (SNA) brings a framework to the table that covers a wide spectrum of indicators along with detailed information on stocks, transactions, revaluations, other flows, and net worth. The SNA is sufficiently flexible to capture social and environmental developments and to support related policy objectives. However, the SNA framework is less well known and, admittedly more complex to interpret.

GDP does not measure environmental degradation or other changes in stocks. Its main role within the SNA is to provide a summary of an economy's output, which can also be presented in terms of income and expenditure. There is an extensive literature on the strengths and limitations of GDP but the broad consensus is that GDP remains a meaningful, popular and widely used economic indicator. ${ }^{2}$

A simple example can illustrate GDP as one indicator in the broader framework of the SNA. In the aftermath of an environmental disaster that destroys significant portions of a country's housing stock, GDP would record expenses (flows) to rebuild homes but it does not record lost property (a stock). The SNA framework reflects the losses to the housing stock in the balance sheets of the household sector and lower net worth as well as flows associated with rebuilding efforts. It also records effects on other sectors that may have been affected such as the government or corporate sectors. The SNA also records the subsequent financial flows associated with rebuilding and adjusts the stocks accordingly at the end of the period. The SNA records activities according to the type of flow, financial instrument, and institutional sectors undertaking the activity. For example, insurance claims received by homeowners, mortgages to finance new homes, government transfers to households would not be reflected directly in GDP but would all be shown as an increase in household net worth.

Using the SNA accounts, it is possible to decouple economic growth - the production of goods and services - from some aspects of environmental degradation as envisioned by Goal

\footnotetext{
2 The literature on this topic goes back to the early days when GDP was developed as the central metric of economic progress, see Stone (1975, 1984), Nordhaus and Tobin (1973). Recently, the International Association of Research on Income and Wealth (IARIW) has held international and regional conferences such as the 2015 IARIW-OECD Special Conference on W(h)ither the SNA? and the IARIW-Bank of Korea Conference Beyond GDP: Experiences and Challenges in the Measurement of Economic Wellbeing. Other contributions to this debate include Stiglitz, Fitoussi, Sen 2009; Coyle 2014, 2017; Klenow, P. J, C.I. Jones, 2016).
} 
8 of the SDGs. A deterioration of sectoral balance sheets reflecting environmental degradation may well coincide with positive growth of economic activity (GDP).

This example illustrates that, rather than attempting to redefine GDP, the focus should be on utilizing the SNA's broad framework more fully. Using the example of the household sector balance sheet, we explore how the SNA framework can accommodate some of the SDGs to measure progress towards achieving these goals and to support policy decisions. To do so, we construct a conceptual "super balance sheet" that combines physical and monetary assets and considers an expanded SNA assets boundary to include human capital, the use of durable consumer goods for household production, and some indicators of social wellbeing and the carbon footprint.

Our work builds on ideas and discussions that go back to the early days of the SNA but were abandoned due to data limitations. In the digital age these data limitations are far less constraining than in the past.

\section{SDGS - WHAT THE SNA BRINGS TO THE TABLE}

\section{A. The SDGs and Multidimensional Measures of Progress}

In 2015, the UN General Assembly adopted 17 SDGs as part of its agenda for sustainable development (Figure 1). The purpose of the SDGs is to achieve sustainable development in its three dimensions - economic, social and environmental — in a balanced and integrated manner with goals to be achieved by 2030. These are further broken into 169 targets and 304 indicators to determine the progress towards meeting these goals.

Various goals and indicators focus on the need for sustainable economic growth, consumption and production, and the need to decouple these activities from natural resource use and environmental degradation. Goal 8 focuses on economic growth and employment and the underlying targets and indicators specify that GDP growth should be decoupled from environmental degradation and linked with sustainable production, consumption, and meaningful jobs.

Goal 12 focuses on targets to ensure sustainable consumption and production. It therefore calls for the development of sustainable consumption and production plans that are integrated into national and sectoral plans, sustainable business practices and consumer behavior. 
Figure 1: United Nations Sustainable Development Goals (SDGs)

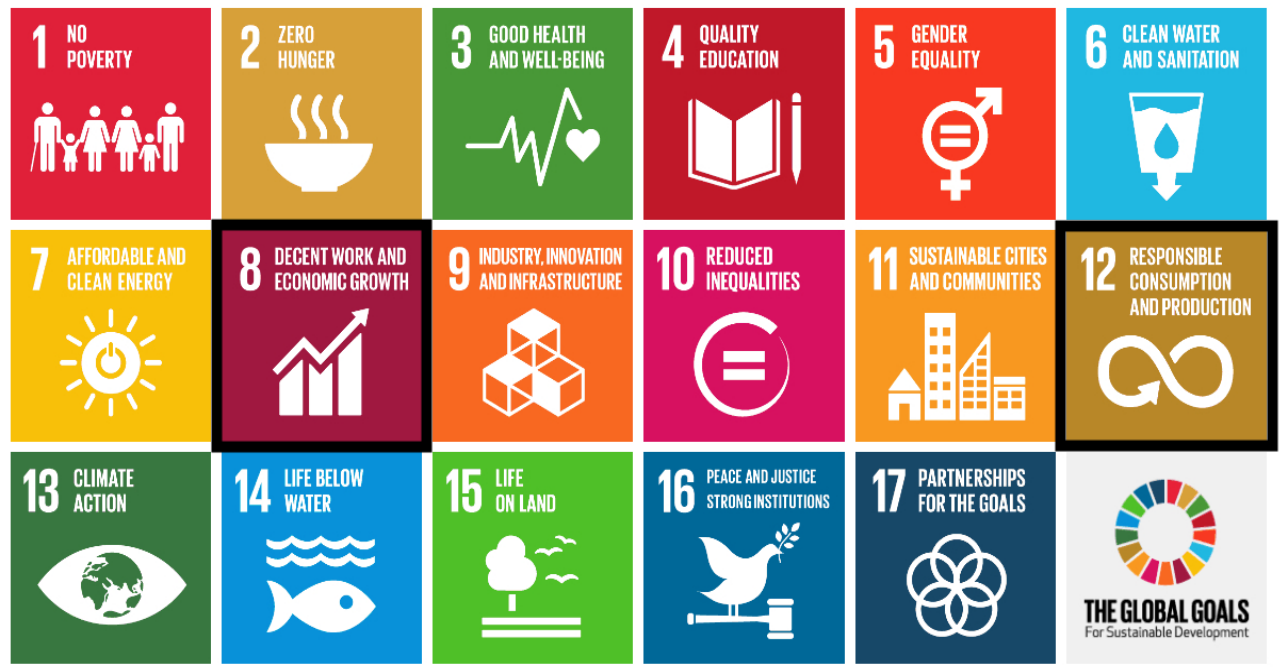

Source: United Nations Development Programme; emphasis on Goals 8 and 12 added by the authors.

The SDGs build upon the achievements of the Millennium Development Goals (MDGs), which were adopted in 2000 and focused on improving living conditions in developing countries (UN 2016).

The SDGs apply to all countries and many countries have already begun to disseminate data. For example, most of the G-20 economies have begun to publish SDG information for their countries or have work programs in place to disseminate regular updates. Several global databases help track progress (OECD, 2015; Sachs, J., et al. 2016; World Bank 2011). In addition, the global statistical community has mapped out a work program to assure that indicators are well defined and comparable across countries.

There are several other prominent examples of multidimensional measures of social progress. The OECD's Better Life Initiative produced a compendium of wellbeing indicators for developed economies and some emerging market economies. The Initiative produces the "How's Life?" Report that includes statistics on the material wellbeing and quality of life (social and environmental factors) of residents of OECD members and partner countries (OECD 2011, 2015). The 2015 edition incorporates the "sustainability of wellbeing over time" domain. It is based on stocks of natural, human, economic, and social capital to assess the extent to which the capital supports wellbeing now and in the future. In addition, individual countries are increasingly embarking on developing wellbeing indicators based on national factors and considerations. ${ }^{3}$

\footnotetext{
${ }^{3}$ For example, the Dutch Cabinet has commissioned Statistics Netherlands to compile an annual monitor of wellbeing. This report is expected to form the basis of the Cabinet's decisions on the state of wellbeing in the Netherlands and part of the debate on the subject in the Dutch Parliament. In Indonesia, the Office of Presidential Staff (KSP), Statistics of Indonesia (BPS, and the Ministry of National Development Planning are developing data portal to monitor, evaluate, and report progress towards meeting SDG goals.
} 


\section{B. GDP and the SNA - A Brief Recount of the Evolution}

The SNA is an internationally agreed standard for measuring economic activity based on a consistent set of accounting principles. It is explicitly designed to support economic policy making, analysis, and assessments. It therefore has a focus on indicators that provide information on the "bottom line" such as GDP, saving, disposable income, debt, and net worth. ${ }^{4}$

During the post-war efforts to rebuild economies, GDP was a convenient and standardized metric that served an important role in evaluating economic growth and a country's production capacity. The growth of GDP was deemed to reflect an increase in individual income, thus leading to the improved wellbeing of a country's citizens. However, it has become clear-especially as economies evolve - that economic growth does not improve lives of all citizens equally.

The limitations of GDP were recognized by the architects of the SNA who also stressed the need to look at a broader range of data to analyze welfare. Discussions regarding the inclusion of some social and demographic indicators have arisen from time to time since the SNA was first released in 1953. The 1968 SNA discussed the possibility of including accounts on human capital stocks and flows in the system in the form of a population matrix. The resulting framework would bring together demographic, educational, and other social statistics that have a bearing on the economic and social characteristics of a population so that the changing structure of that population in terms of these characteristics, can be measured. Therefore, the population matrices would be developed to show population flows (through births, deaths, and migration) and stocks. The 1968 SNA saw the goal as linking the two systems based on their common attributes and relationships (1968 SNA paragraph 1.91).

Richard Stone (1975) one of the SNA's architects proposed a system of social and demographic statistics to cover all aspects of social life that may require policy action. The system was designed to show what data are available and useful to analyze the interactions of households with each other and with other units. Stone's framework was designed to link environmental statistics to the System of Environmental Economic Accounting (SEEA) which was in the process of development at the time and published subsequently. It does not cover politics because the difficulty of measurement and analysis.

Stone also illustrated how an accounting framework can be used to describe and understand society. He noted that the three pillars on which the analysis of society ought to rest are studies of economic, socio-demographic, and environmental phenomena. Thus, the

\footnotetext{
${ }^{4}$ The United Nations Statistical Division (UNSD) maintains a website on the SNA including earlier versions and related materials. https://unstats.un.org/unsd/nationalaccount/sna.asp. The SNA is updated periodically through a global process of consultation involving an expert group of national accounts professionals (Advisory Expert Group) and a team of international organizations, the Inter-Secretariat Working Group on National Accounts (ISWGNA) currently chaired by the IMF.
} 
accounting structure can provide a coherent picture of the stocks and flows of the variables associated with these phenomena. Stone was of the view that the accounting principles used for national economic accounting could be extended to the broader analysis of society. In the digital age with accounting principles universally accepted and data structured accordingly, the idea of a broader SNA framework regains a new relevance and is far more realistic.

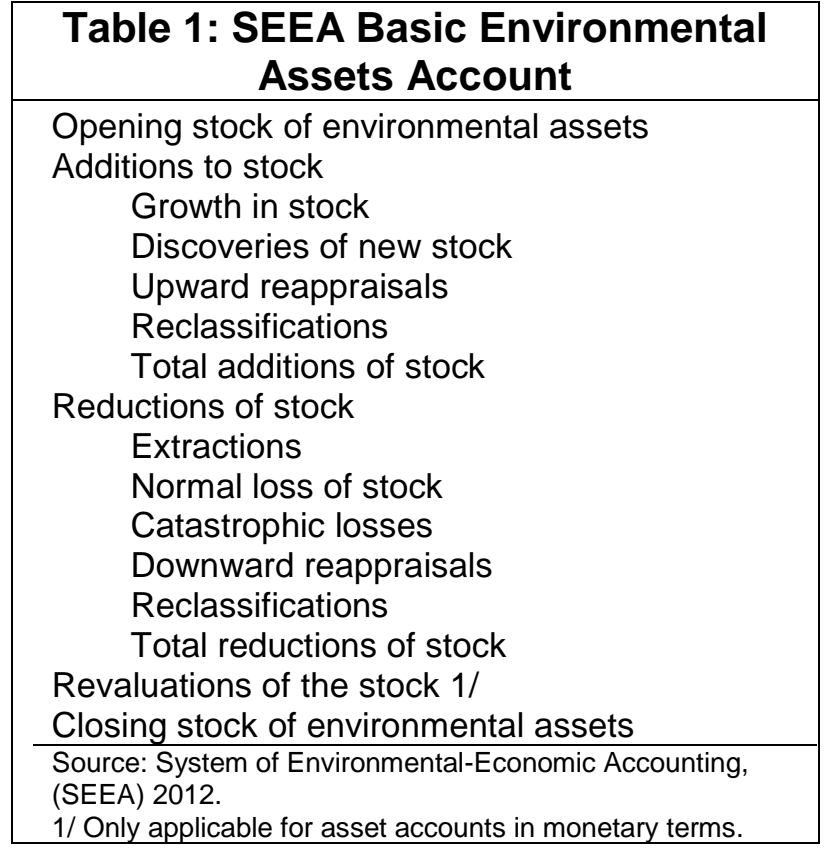

Full balance sheets were introduced into the SNA framework in the 1993 edition and in 2011, the System of Environmental Accounts (SEEA) was added to capture environmental degradation and other externalities. The SEEA introduced a mix of physical and assets and assets expressed in monetary terms into the accounting framework to help measure externalities that are, by definition, not adequately priced by the market (Table 1). Other statistical manuals cover the informal sector, human capital measures, sociodemographics, and other areas (Liu, 2011; OECD, 2013; UN 1975; UNECE 2011 and 2016).

\section{The Relevance of National Accounts to the SDGs}

National accounts are an overarching framework that reflects all economic actions undertaken by economic agents in the economy. The SNA presents these actions within a sequence of interlinked accounts. The economic agents are grouped together into five main sectors, based on their behavior, functions, and objectives. The five main sectors (S11 - S15) are households, financial corporations, non-financial corporations, government, and nonprofit institutions serving households, complemented by the external or rest of the world sector (Figure 2). 
Figure 2: The SNA Splits the Economy into Institutional Sectors

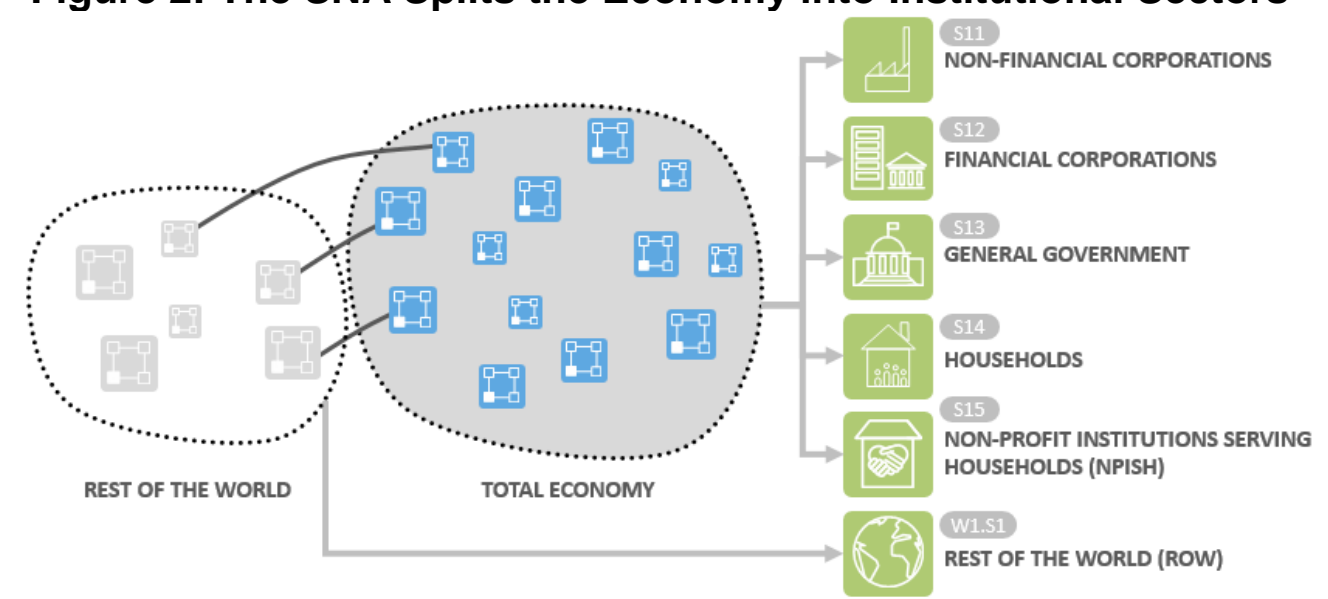

Source: System of National Accounts 2008 (2008 SNA).

The SNA lays out full balance sheets and income statements for each sector to measure the net worth position as an important bottom line. As part of the consistent framework, the SNA shows how wealth is created and accumulated. Figure 3 presents the overall net worth (wealth) of selected countries along with GDP growth figures to highlight that GDP growth and net worth together can provide a snapshot on whether distribution of wealth across countries is converging or drifting apart. Similar charts can be prepared on a per capita basis to correct for population size, or for the sectors of one country such as the household or corporate sectors to analyze distribution within or across sectors and the evolution over time.

The sectoral data of the national accounts framework can be used to study how the costs of an initial shock may be redistributed to various sectors over time. For example, a banking crisis may affect the financial sector in the first instance but redistribute the burden to the government and corporate sectors in the longer term (Frecaut, 2017). In short, the SNA specifies the wealth of each sector and linkages across sectors over time by tracing flows.

The sectoral accounts or balance sheets of the SNA (sometimes referred to as flow of funds statistics), have gained prominence for policy in the aftermath of the 2008 financial crisis. The G-20 Data Gaps Initiative (DGI, 2016), launched in the aftermath of the crisis includes, as one of its recommendations, the development of balance sheets for each sector. The SNA is universally recognized and it is applied, although not always to its full extent, in most countries, making the statistical concepts and the disseminated data globally comparable. To date, all OECD member countries and some emerging market economies disseminate sectoral accounts and balance sheet statistics. 
Figure 3: SNA - Measures of Wealth of Countries and Changes Over Time

The SNA's net worth is a measure of wealth.

GDP growth indicates its direction of change over time.

Selected countries, 2016

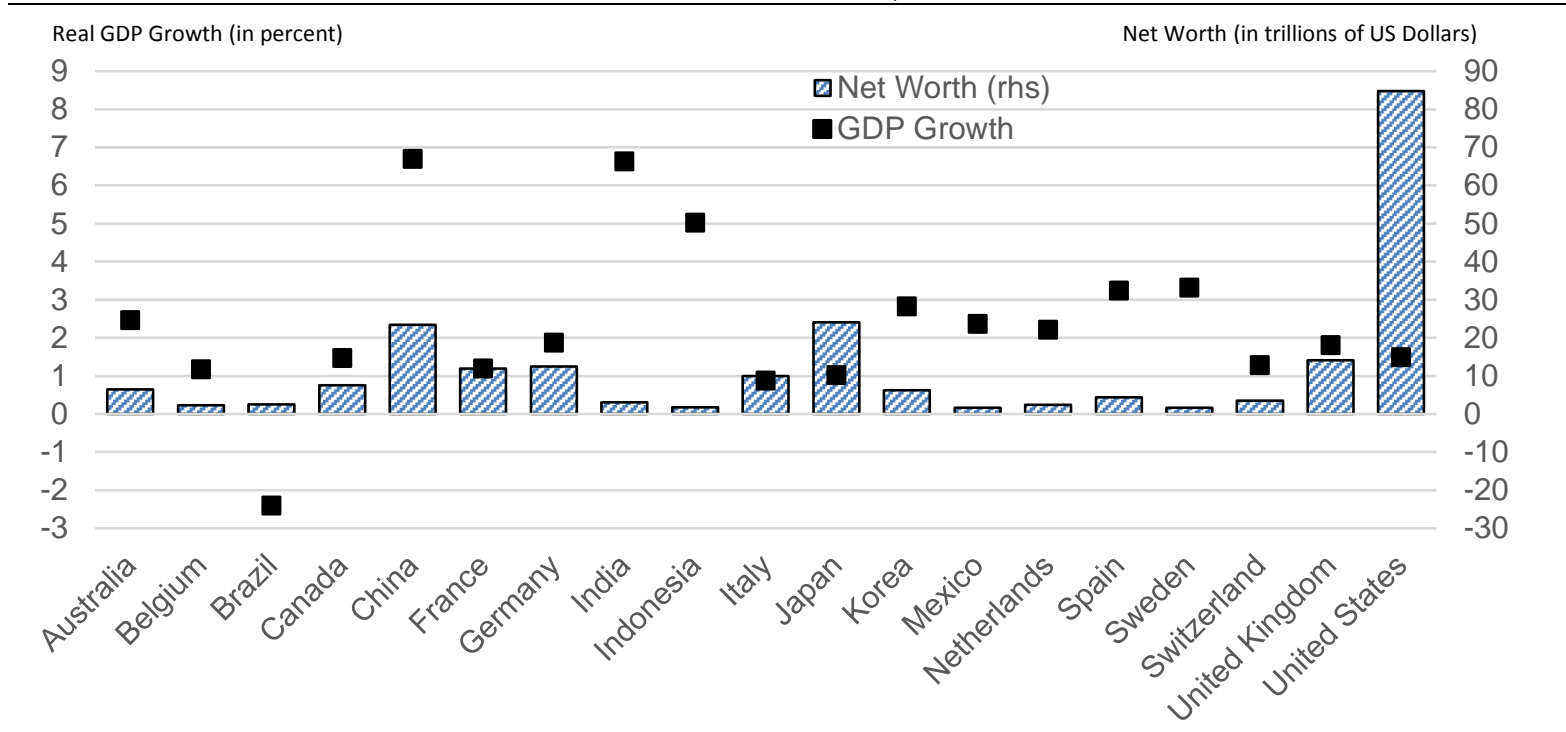

Source: International Financial Statistics (IFS); Credit Suisse (2016) The SNA covers similar measures for each sector of the economy and thus supports analysis of sectoral and global redistribution over time.

A useful feature of the SNA is that it allows for the development of satellite accounts, where the broad structure of the SNA is maintained but some of the conventions of the central framework may be relaxed. In this case, the definition of assets is relaxed to allow the scope of assets - and the production boundary - to be expanded. The proposed approach maintains the principles of the SNA accounting framework. The use of a satellite accounting framework allows for conceptual variations from the central framework of the SNA (Harrison, 2006).

\section{The SNA HouSEHOLd SECTOR AND EXTENDED ASSET BOUNDARY}

The SNA can be used to measure and analyze wellbeing and the effects of social and environmental factors such as environmental degradation. We use the example of the household sector to illustrate how the SNA can be applied to gauge sustainable economic growth, production and consumption. Starting with the conventional SNA balance sheet for households, we build a "super balance sheet" that covers extended assets and that could be presented as a satellite account for the household sector to reflect social and environmental dimensions contained in the SDGs.

The household sector is central to the economy and the dynamics of household consumption is a major driver of economic activity. Household demand for durable goods (cars, computers, furniture), nondurable goods (food, cosmetics, clothing), services (entertainment, 
education, health) as well as assets (dwellings) is a key indicator of economic growth. ${ }^{5}$ Consumption constitutes the largest component of GDP (Table 2). Consumption is undertaken either by households directly (household final consumption expenditure), by governments (for the community at large), and by non-profit institutions serving households. The household sector is also central to measuring poverty.

\begin{tabular}{lclc}
\hline \multicolumn{4}{c}{ Table 2: Household Expenditure by Region } \\
(Final Consumption, in percent of GDP, 2016) \\
\hline World & 58.3 & South Asia & 56.3 \\
East Asia and Pacific & 49.4 & Latin America \& Caribbean & 65.3 \\
Middle East and North Africa & 50.3 & North America & 67.1 \\
Europe and Central Asia & 56.3 & Sub-Saharan Africa & 69.9 \\
\hline
\end{tabular}

Source: World Bank.

\section{A. The SNA Balance Sheet for the Household Sector}

The 2008 SNA framework proposes a standard presentation of balance sheets for the household sector, based on the same instrument classification and items used for other sectors of the economy. However, the instruments and items of importance to households are different from what may be important to other legal and social entities. Figure 4 provides an example of the evolution of the U.S. household sector balance sheets, broken down by instruments, over a 17-year period. It shows how various assets, liabilities, and net worth evolved over time. These data could also be shown separately, by instrument or by household percentiles to highlight distributional aspects or indicators of poverty.

The instrument breakdown will be different across countries and across segments of the population. For example, the assets side of the household balance sheet may comprise a limited number of financial instruments, the main one being deposits. Depending on the degree of financial sophistication of the economy, household assets may also include claims on enterprises and investment in financial assets outside pension funds. The nonfinancial assets constitute mainly dwellings and land. The liabilities may comprise mainly mortgages and consumer debt. Households that undertake production for the market may also include other fixed assets on their balance sheet, such as vehicles, machinery and equipment, and inventories.

\footnotetext{
5 The 2008 financial crisis highlighted the importance of the household sector. The fall in the household wealth, due to the housing market and stock markets collapse, as well as increased unemployment and overall uncertainty, resulted in a sharp decline in private sector demand. Regardless of the drivers of this subdued consumption (wealth effect, low confidence, uncertainty), this drag on the economy proved to be persistent, making recovery process slow and largely dependent on the uptake in households' consumption.
} 
Figure 4: United States: SNA-Based Household Sector Balance Sheet (in trillions of US Dollars)

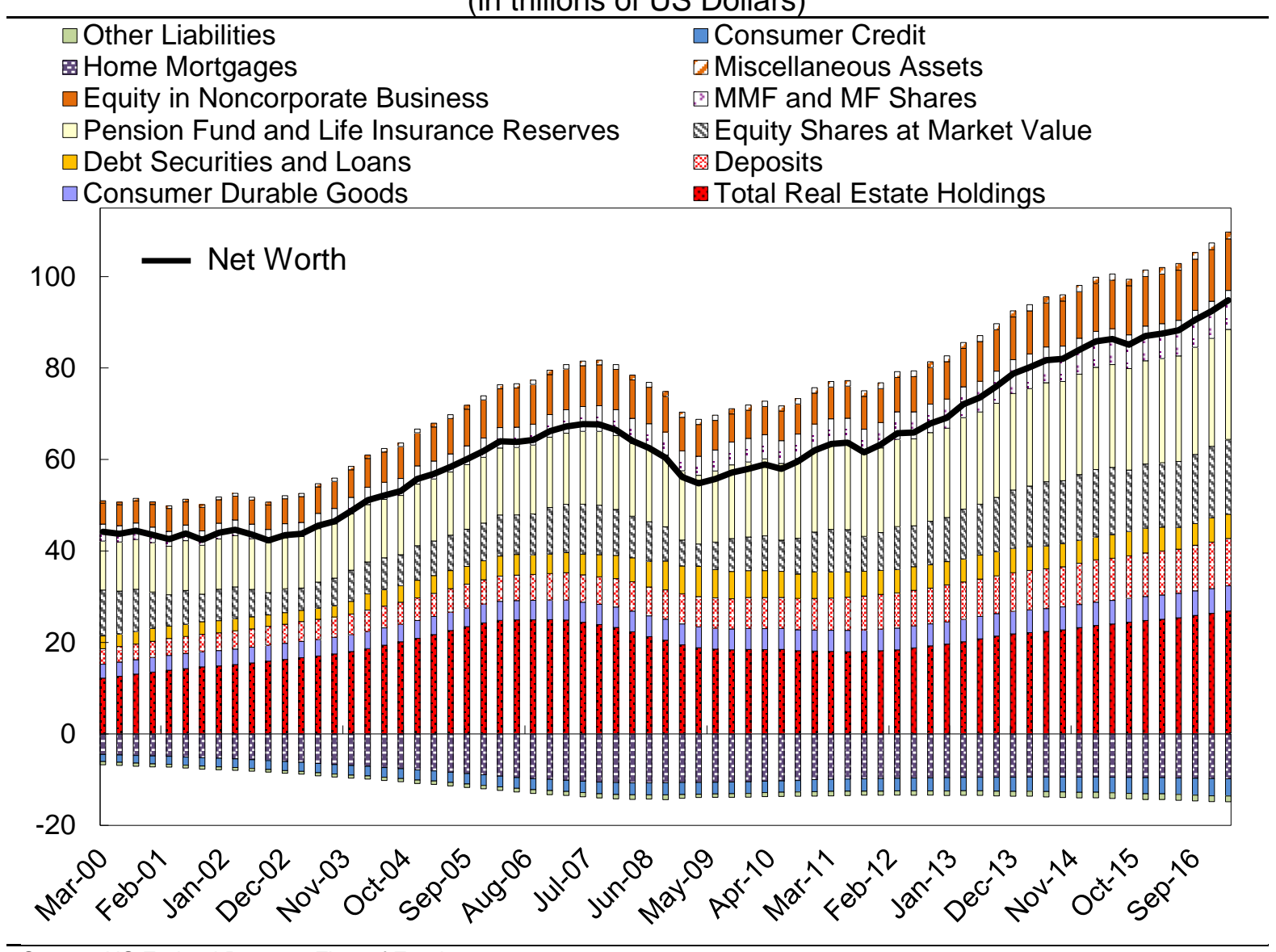

Source: US Federal Reserve Flow of Funds.

\section{B. The Expanded SNA Assets Boundary}

The SNA excludes from the production boundary, services produced by households for its own consumption. Thus, the inclusion of goods produced on own-account, but the exclusion of services produced for own consumption, remain at the core of the SNA production boundary. The exclusion of services produced for own consumption from the production boundary was based on practical consideration and the SNA implicitly acknowledges that a broadening of the asset boundary can be considered with data availability.

The primary reason is that the cost of these services could not be easily measured because these services are provided for free or cannot be easily differentiated from the activities related to living (Stone, 1984). However, digitization has facilitated a transformation of household wealth by allowing the household to produce and exchange services using skills and durable consumer goods. The 2008 SNA defines assets as "...entities that must be owned by some unit, or units, and from which economic benefits are derived by their owner(s) by holding or using them over a period of time" (2008 SNA paragraph 1.46). This definition identifies two critical criteria for determining an asset: (i) ownership by a unit or units; 
(ii) the ability to provide economic benefits. The identification of ownership may be relatively straightforward for financial assets and produced assets because there are identified with a specific unit (household or legal entity) when they are created or acquired.

In terms of non-produced assets such as natural resources, identifying or assigning ownership may not be so clear-cut because, they are not subject to a production process and the entity may be immovable, and therefore not deemed to be exchangeable. In identifying nonproduced assets, the focus is on whether the institutional unit can establish effective ownership and benefit from these assets. For financial assets, there is no need to broaden the asset boundary.

The production and assets boundaries of the SNA do not include social and environment indicators. The measurement and assessment of these indicators based on an SNA framework would require an expansion of the SNA production and asset boundaries. The criterion that the entity must be subject to ownership by a unit or units to be considered an asset may not hold for social and environmental entities that are not subject to ownership, or that are owned by the society as a whole. ${ }^{6}$ However, even when the entity is not subject to ownership households can receive benefits from these entities. In addition, entities owned by the society that provide benefits to households are not reflected on household balance sheets. Therefore, cross country comparisons of household assets may understate the benefits derived by households for economies where household ownership of assets is low. In this case, the overarching criterion is whether the entity can provide an economic benefit to the household.

Consumer durables are not considered household assets in the SNA, but are considered household final consumption expenditure. In this regard, consumer durables, are recorded in the use of income accounts as flows, and not as stocks in the balance sheets. Households with unincorporated enterprises may also include some fixed assets; however, this may be small and represent a very small fraction of overall household assets. The classification of consumer durables as expenditure coincides with the function of households as being consumers and not as producers, as are corporations. The inclusion of consumer durables in the SNA assets boundary also implies that household services on own account be included, thereby expanding the SNA production boundary.

Based on this restriction, consumer durables and human capital are not considered capable of bringing economic benefit to their owners and are not considered assets. The 2008 SNA notes further, "...consumer durables are not regarded as assets in the SNA because the services they provide are not within the production boundary. Human capital is not treated by the SNA as an asset as it is difficult to envisage "ownership rights" in connection with people, and even if this were sidestepped, the question of valuation is not very tractable." The asset

\footnotetext{
${ }^{6}$ The balance sheet of the household sector for a given economy is an aggregate of the balance sheets of the individual household units. Therefore, assets owned by the community but provide benefits to households are not included in the assets of the household sector.
} 
boundary is extended to account for entities over which ownership rights are not established and are therefore not liable to being exchanged. In this regard, the overarching criterion is whether the entity can provide an economic benefit to the household.

In this paper, we follow the 2008 SNA definition and scope of households as " ... a group of persons who share the same living accommodation, who pool some, or all, of their income and wealth and who consume certain types of goods and services collectively, mainly housing and food." The scope includes institutional households. In addition, the production activities of households that generate income are also included in the household sector, if the production income or the related financial transactions cannot be differentiated from the other activities of the household. The production activity is therefore deemed to be undertaken by a household unincorporated enterprise.

Based on the expanded scope of assets used in this paper, and the concomitant expanded scope of the production boundary, it is expected the activities of households would increase substantially, although there is no change in the scope of households.

\section{BUILDING AN EXTENDED "SUPER BALANCE SHEET"}

Starting with the SNA balance sheet for households, we develop a "Super Balance Sheet" with an expanded asset boundary to include durable consumer goods used to produce services, human capital, and access to resources such as clean water and air, education, health, and infrastructure, to produce an expanded household net worth. Such information can also be presented to highlight characteristics by region, by gender, or distribution of income and wealth. The expansion of data availability with digital and geospatial information makes it possible to construct Super Balance Sheets.

Table 3 presents the SNA prototype of a balance sheet showing the typical financial assets and liabilities and nonfinancial assets that may be included.

\begin{tabular}{|c|c|}
\hline ASSETS & LIABILITIES \\
\hline \multirow{2}{*}{$\begin{array}{l}\text { Financial assets } \\
\text { Currency and Deposits } \\
\text { Equity (stocks, bonds, other securities) } \\
\text { Insurance reserves/Pension entitlements } \\
\text { Other financial assets } \\
\text { Non-financial assets } \\
\text { Owner-occupied Dwellings } \\
\text { Other real property } \\
\text { Other non-financial assets }\end{array}$} & $\begin{array}{l}\text { Liabilities } \\
\text { Loans (Mortgage, credit card debt, } \\
\text { student loans, other consumer loans) } \\
\text { Other liabilities }\end{array}$ \\
\hline & $\begin{array}{l}\text { Net worth = } \\
\quad \text { ASSETS minus LIABILITIES }\end{array}$ \\
\hline
\end{tabular}

Source: The System of National Accounts, 2008 (2008 SNA). 
Table 4 presents a "super" balance sheet of households which includes various sustainability indicators.

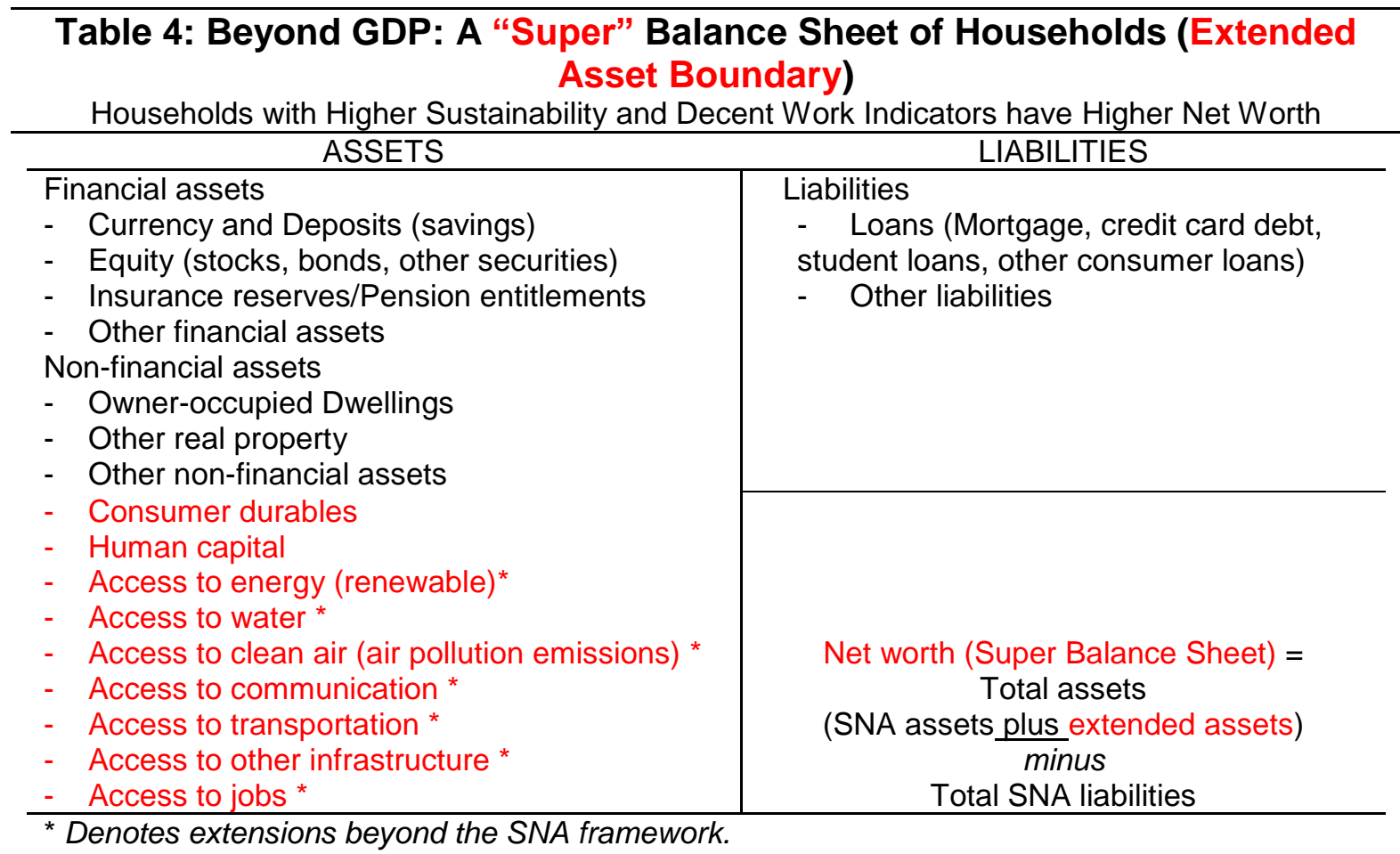

As a first step, we propose the inclusion of consumer durables as assets of households. The inclusion of consumer durables in the asset boundary is in line with the expansion of the production boundary to include household services provided to other households. With the expansion of the "sharing economy," consumer durables are playing an increasingly important role in generating household income and improving household wealth. There has been quite a lot of interest and work on including consumer durable goods in household assets and the effect on wealth. The Canberra Group Handbook on Household Income Statistics (2011) includes the services from consumer durables in the conceptual definition of income, which implies that consumer durables are to be treated as household assets-like dwellings - that produce these services.

Recognizing the importance of this information for policy analysis, the 2008 SNA recommends that statistics on consumer durables be included as a memorandum item to the balance sheets. Some advanced economies have gone beyond the SNA recommendations and included consumer durables as assets in the balance sheets of the household sector. Thus, increased expenditure of consumer durables is not seen simply to increase household consumption, but also a means of facilitating household production.

The inclusion of human capital and demographic statistics in the SNA framework was discussed during the preparation of the 1968 SNA. However, the idea was abandoned, in part, due to the lack of data and a measurement framework. Both the 1993 SNA and 2008 SNA 
acknowledge the importance of human capital but stress its incompatibility with the SNA definition of assets and the difficulties that valuation and measurement may pose.

The measurement of human capital as assets is addressed in the Guide to Measuring Human Capital (2016), which puts forward a framework for its measurement. It only considers human capital developed through educational attainment and job-related training. The importance of own-account services is recognized as the Guide extends the SNA production boundary to include own-account training.

The extended balance sheets also include environmental assets as households receive a range of benefits from the environment. It builds on the SEEA which presents a comprehensive system of flows and stocks that describes the relationship between the economy and the environment. It uses the concepts, framework, and principles of the SNA as a basis to compile physical accounts and tables, and assets accounts for natural resources. The SEEA therefore allows for the integration of the physical components of environmental information with the monetary framework used for economic statistics.

The SEEA defines environmental assets as the naturally occurring living and non-living components of the Earth, together constituting the biophysical environment, which may provide benefits to humanity (2012 SEEA paragraph 2.17). The definition therefore covers assets that are naturally occurring in the environment as well as environmental assets that have been transformed by economic activity, or they may be. Although they are naturally occurring, many environmental assets are transformed to varying degrees by economic activities. The SEEA therefore extends the SNA asset boundary to not only include assets under the ownership and control of an institutional unit, but all naturally occurring assets that may provide benefits. It therefore does not follow the requirement that the entity must be able to provide economic benefits to its owner.

The framework of the extended balance sheet is expanded further to include other social assets. The inclusion of these assets is based on the ability of households to access the benefits. This access is therefore an indicator of future consumption where future consumption is the stream of benefits that can accrue to the household as a result of owning (as a society) and using the asset.

The range of assets that may be included is potentially broad; therefore, the scope of assets is restricted to produced assets and non-produced assets for which a valuation is available. The super balance sheet may include a range items. It could be reduced to facilitate cross country comparison or expanded based on the set of countries being considered.

\section{A. Data Sources}

Development of an extended balance sheet of environmental and social statistics requires a range of data on the activities of individual households. The growing involvement of 
household in digitization has presented a range of possibilities for collecting data on household activities (Hammer, Kostroch, Quiros, 2017). The extended balance sheet framework can be presented in the form of satellite accounts for the household sector taking account of indicators of the SDGs. The extended super balance sheet (Table 4) is not an allencompassing framework for the SDGs and may not produce a linear relationship. Thus, components of the balance sheet may address a cross-section of SDGs. Further, the extended balance sheet will not represent all SDGs and will also present balance sheet items for which data are available.

The digital revolution has extended the boundaries of data computing, processing, and availability beyond expectations. Increasingly detailed, high frequency, and timely information about households will, over time, will improve estimations of household wealth. Household surveys have been a common method for collecting these data, but it is time consuming and expensive. Other administrative data may be less resource-intensive and more timely, but limited in scope and usually not available to researchers, or other governmental organizations.

\section{CONCLUSION}

The SNA provides a framework that can accommodate a broad set of indicators and can contribute significantly to the measures of progress in achieving the SDGs. This paper proposes the development of an extended SNA-based "Super Balance Sheet" for households to accommodate multidimensional indicators and to provide a more comprehensive gauge of sustainable economic growth, consumption and production, while taking account of the need to decouple these activities from natural resource use and environmental degradation. It therefore highlights the importance of the availability and efficient use of resources for future production, and hence consumption.

The balance sheets discussed in this paper focus on the household sector, in recognizing the sector's significant role as final consumer. Therefore, since it is not feasible to allocate the ownership of environmental assets across institutional units, these assets are allocated to the household sector. The development of super balance sheets for other sectors would require an allocation of environmental assets to the units and sectors with a direct benefit.

The SNA includes net worth as a "bottom line" for institutional sectors and the total economy. The expansion of the production and asset boundaries will lead to higher estimates of household production, assets, and hence household net worth. An expanded net worth as presented in this paper therefore provides a broader description of the household's wealth. For global comparisons, the super balance sheet will highlight the state of global inequality and its evolution over time. For example, while access to water is virtually universal in advanced economies, in low income countries, significant strata of the population do not 
have access to water. Linking the SNA with sustainable development indicators can be a powerful tool for policy analysis.

Ownership of consumer durables enhances the household's ability to engage in household production and improves opportunities for "decent work" as referred to in Goal 8 of the SDGs. The super balance sheet will generally increase the ratio of non-financial assets to financial assets. In general, the super balance sheet will highlight that social and environmental advantages including some of the indicators of SDG Goal 12 are reflected in higher net worth. Conversely, environmental degradation or less meaningful work will result in lower net worth.

As data evolve, the system can be expanded and analysts may decide, along the way, how to account for the various indicators. Therefore, the next step in this exercise is to develop a super balance sheet using actual country data. 


\section{REFERENCES}

Boarini, R., G. Liu, M. Mira d'Ercole, 2012, "Approaches to Measuring the Stock of Human Capital: A Review of Country Practice,” OECD Statistics Working Papers, No. 2012/04.

Data Gaps Initiative (DGI), 2016 Second Phase of the G-20 Data Gaps Initiative, First Progress Report. Prepared by the Staff of the IMF and FSB Secretariat.

Doyle, D., 2014, “GDP: A Brief but Affectionate History,” Princeton University Press. , 2017, "Rethinking GDP,” Finance and Development, Vol. 54, No. 1, March.

Deutsche Bundesbank, 2003, "Monthly Report,” Deutsche Bundesbank, Vol. 55, No. 7.

European Central Bank, 2016, “The Household Finance and Consumption Survey: Results from the Second Wave," ECB Statistics, No 18.

European Commission, IMF, OECD, United Nations, and World Bank. 2009. System of National Accounts 2008. New York, United Nations.

European Commission, FAO, IMF, OECD, United Nations, and World Bank, 2014. System of Environmental-Economic Accounting-Central Framework, 2012

Fraumeni, B. M., G. Liu, 2014, "Human capital measurement: country experiences and international initiatives," In D. Jorgenson, K. Fukao, \& M. Timmer (Eds.), “The World Economy: Growth or Stagnation?"

Frecaut, Olivier, 2017, "Systemic banking crises: completing the enhanced policy responses," Journal of Financial Regulation and Compliance. Vol. 25 Issue: 4, pp.381-395.

FSB, IMF, 2017, "FSB and IMF Report on Progress with G20 Data Gaps Initiative (DGI-2)," Second Progress Report.

Hamilton, K, G. Liu, 2013, "Human Capital, Tangible Wealth and the Intangible capital residual,” OECD Working Paper, No. 51.

Hammer, C. Kostroch, D., and Quiros G., 2017, "Big Data: Potential, Challenges, and Statistical Implications” IMF Staff Discussion Note (SDN/06/17).

Harrison, Ann, 2006, "Clarification on Chapter XXI on Satellite Accounts," $4^{\text {th }}$ Meeting of the Advisory Expert Group on National Accounts, Frankfurt, SNA/M1.06/37. https://unstats.un.org/unsd/nationalaccount/iswgna.asp. 
Helliwell, J., R. Layard, J. Sachs, 2017, “World Happiness Report 2017,” New York: Sustainable Development Solutions Network.

Hutton, G., M. Varughese, 2016, “The Costs of Meeting the 2030 Sustainable Development Goal Targets on Drinking Water, Sanitation, and Hygiene," Washington, D.C.: World Bank Group.

International Association of Research on Income and Wealth (IARIW), 2015 IARIW-OECD Special Conference on "W(h)ither the SNA?"

Klenow, P. J, C.I. Jones, 2016, "Beyond GDP? Welfare across Countries and Time," American Economic Review, 106(9) pp. 2426-2457.

Lequiller, F. and D. Blades, Understanding National Accounts, $2^{\text {nd }}$ edition: OECD Publishing.

Liu, G., 2011, "Measuring the stock of human capital for comparative analysis: An application of the lifetime income approach to selected countries", OECD Working Paper, No. 41.

Nordhaus W.D. and J. Tobin (1973) "Is Growth Obsolete?" in “The Measurement of Economic and Social Performance, Studies in Income and Wealth, National Bureau of Economic Research, Vol. 38.

OECD, 2013, OECD Guidelines for Micro Statistics on Household Wealth, OECD Publishing.

OECD, 2015, How's Life? 2015: Measuring Wellbeing, OECD Publishing.

Sachs, J., Schmidt-Traub, G., Kroll, C., Durand-Delacre, D., and Teksoz, K. (2016) SDG Index and Dashboards - Global Report. New York: Bertelsmann Stiftung and Sustainable Development Solutions Netwoek (SDSN).

Shorrocks, A., Davies, J., Lluberas, R., Koutsoukis, A. 2016, "Global Wealth Report 2016," Credit Suisse AG, Zurich.

Stiglitz J. E., A. Sen, J. Fitoussi, 2009, "Report by the Commission on the Measurement of Economic Performance and Social Progress."

Stone, Richard (1975) System of Social and Demographic Statistics, United Nations, 1975

----, 1984, Economic Sciences, Nobel Memorial Lecture-The Accounts of Society.

United Nations, 1968, System of National Accounts 1968, Studies in Methods, Series F No 2, New York. 
----, 1975. Towards a System of Social and Demographic Statistics, Studies in Methods, Series F No 8, New York.

---- 2015, “The Millennium Development Goals Report 2015,” New York.

United Nations Economic Commission for Europe (UNECE), 2011, The Canberra Group Handbook on Household Income Statistics, Geneva.

------ 2016, “Guide on Measuring Human Capital,” Conference of European Statisticians. United Nations Development Programme (UNDP), 1990, "Human Development Report," (New York: Oxford University Press).

United Nations Statistical Commission (UNSC), 2015, Interagency Expert Group on SDG Indicators https://unstats.un.org/sdgs/iaeg-sdgs.

World Bank, 2011, "The Changing Wealth of Nations: Measuring Sustainable Development in the New Millennium" World Bank Group.

----, 2016, “World Development Report 2016: Digital Dividends," Washington, D.C.: World Bank Group. 